\title{
Winter Conditions Correlate with Phytophthora alni Subspecies Distribution in Southern Sweden
}

\author{
Miguel A. Redondo, Johanna Boberg, Christer H. B. Olsson, and Jonàs Oliva
}

First, second, and fourth authors: Department of Forest Mycology and Plant Pathology, Swedish University of Agricultural Sciences, Box 7026, 75007 Uppsala, Sweden; and third author: Department of Biological and Environmental Sciences, Gothenburg University, Box 461, 40530 Göteborg, Sweden.

Accepted for publication 24 March 2015.

\begin{abstract}
Redondo, M. A., Boberg, J., Olsson, C. H. B., and Oliva, J. 2015. Winter conditions correlate with Phytophthora alni subspecies distribution in southern Sweden. Phytopathology 105:1191-1197.

During the last century, the number of forest pathogen invasions has increased substantially. Environmental variables can play a crucial role in determining the establishment of invasive species. The objective of the present work was to determine the correlation between winter climatic conditions and distribution of two subspecies of the invasive forest pathogen Phytophthora alni: P. alni subspp. alni and uniformis killing black alder (Alnus glutinosa) in southern Sweden. It is known from laboratory experiments that $P$. alni subsp. alni is more pathogenic than $P$. alni subsp. uniformis, and that

species, we could investigate whether winter conditions can affect the geographical distribution of $P$. alni subsp. alni spreading northward. Sixteen major river systems of southern Sweden were systematically surveyed and isolations were performed from active cankers. The distribution of the two studied subspecies was highly correlated with winter temperature and duration of periods with heavy frost. While P. alni subsp. uniformis covered the whole range of temperatures of the host, $P$. alni subsp. alni was recovered in areas subjected to milder winter temperatures and shorter frost periods. Our observations suggest that winter conditions can play an important role in limiting P. alni subsp. alni establishment in cold locations, thus affecting the distribution of the different subspecies of $P$. alni in boreal regions.
\end{abstract} $P$. alni subsp. alni is sensitive to low temperatures and long frost periods. By studying the distribution of these two subspecies at the northern limit of the host
Additional keywords: Alnus spp., invasiveness, Phytophthora plurivora.
During the last century, the number of forest pathogen invasions has drastically increased owing to an escalation of international trade bringing together evolutionarily distant host-pathogen combinations (Stenlid et al. 2011). Following introduction, invasive pathogens must be able to establish and spread in the new environment, and it has been suggested that temperature can pose a major barrier at the establishment phase for some pathogens (Sturrock et al. 2011). Future warmer climates could make forest pathogens overcome environmental thresholds that limited their activity earlier and, subsequently, increase their damage (Bergot et al. 2004; Brasier 1996; Dukes et al. 2009; Fabre et al. 2011; Ireland et al. 2013; Santini et al. 2013; Woods et al. 2005).

A significant example of the correlation between temperature and invasiveness is illustrated by the emergence of Phytophthora alni damage in Europe (Aguayo et al. 2014). P. alni is a tree pathogen that causes dieback and mortality in alder species (Alnus spp.). The symptoms associated with $P$. alni include excessive seed production and small, yellow, sparse foliage with premature leaf fall. Infected trees display tongue-shaped exudating cankers, often with reddishbrown phloem tissue starting from the root collar that sometimes is surrounded by black or rusty-colored exudates (Gibbs et al. 1999; Jung and Blaschke 2004; Schumacher et al. 2006) (Supplementary Fig. S1). P. alni was first reported in southern Britain during the early 1990s causing disease on alder (Brasier et al. 1995; Gibbs 1995). Since this first report, the pathogen has been observed across Europe and some parts of North America (Adams et al. 2010;

Corresponding author: M. A. Redondo; E-mail address: miguel.angel.redondo@slu.se

*The $\boldsymbol{e}$-Xtra logo stands for "electronic extra" and indicates that one supplementary figure is published online.

http://dx.doi.org/10.1094/PHYTO-01-15-0020-R

(C) 2015 The American Phytopathological Society
Gibbs et al. 2003; Jung and Blaschke 2004; Olsson 1999; Streito et al. 2002). Within the European continent, Scandinavian countries constitute the northern limit to the distribution of $P$. alni. Initial isozyme studies considered $P$. alni to be a hybrid complex and divided it into three groups (Olsson 1999). Finally, Brasier et al. (2004) described the pathogen as Phytophthora alni and divided it into three subspecies: $P$. alni subsp. alni, corresponding with the standard type; P. alni subsp. uniformis, coinciding with the Swedish variant; and P. alni subsp. multiformis, which included the Dutch, German, and U.K. variant hybrid types.

There are significant differences between $P$. alni subspecies regarding pathogenicity and cold tolerance. In pathogenicity tests, P. alni subsp. alni was more aggressive when infecting Alnus glutinosa compared with P. alni subsp. uniformis (Brasier and Kirk 2001; Santini et al. 2003). P. alni subsp. alni has also shown a low tolerance to long frost periods under laboratory conditions (Černý et al. 2012; Schumacher et al. 2006) and in natural environments (Aguayo et al. 2014; Černý and Strnadová 2012). In addition, $P$. alni subsp. uniformis has been found in locations with harsh winter conditions such as Alaska or Sweden, which could suggest a higher cold tolerance than $P$. alni subsp. alni.

In this work, we studied the distribution of $P$. alni infecting alder in Sweden. Both P. alni subspp. uniformis and alni have been present in Sweden since the 1990s, when they were first observed in the Säveån and Mölndalsån river systems (in 1996 and 1998, respectively) along the west coast near Gothenburg, and in an alder nursery at Ljungbyhed irrigated with water from the Rönne å river (in 1997) (Olsson 1999). Later surveys performed in the Rönne å river system in southern Sweden and in Klarälven (A. incana) in the city of Karlstad in 2006 and 2010 confirmed the presence of P. alni subspp. alni and uniformis in these parts of Sweden (C. H. B. Olsson, unpublished results). In 2013, we performed a comprehensive systematic sampling in South Sweden covering 16 rivers in 
order to (i) assess the current distribution of $P$. alni subspecies and (ii) investigate the correlation between the distribution of the different subspecies and the winter temperature and length of continuous frost periods. We found that $P$. alni subsp. alni, despite being more pathogenic, was only isolated in areas with mild winters, whereas $P$. alni subsp. uniformis was recovered all over the studied area. Our study showed that there is a strong correlation between the winter conditions and the distribution of $P$. alni subspp. alni and uniformis isolates.

\section{MATERIALS AND METHODS}

Field survey. We surveyed 16 major rivers along both the eastern and western coast of southern Sweden from September to November 2013 (Table 1; Fig. 1). In each river, 11 sampling plots were systematically established along the entire stream. In total, 176 plots were surveyed. In every sampling plot, all alder trees located at river banks or at river-connected swamps within a radius of approximately $100 \mathrm{~m}$ from the center of the plot were inspected for active Phytophthora cankers. Active cankers were typically observed as black tarry spots in exposed coarse roots or at the base of the stem. Lesions with unclear symptoms were confirmed to be caused by Phytophthora spp. by using a Phytophthora detection kit (Phytophthora spp. ALERT-LF; Neogen). From each lesion, the bark was removed to expose a brownish, flame-shaped active front, from where approximately $351-\mathrm{mm}$ slices of phloem tissue were directly plated onto four plates of CMA-PARPHB selective medium (Jeffers and Martin 1986; Pérez-Sierra et al. 2010). The plates were kept cool (approximately $10^{\circ} \mathrm{C}$ ) during the fieldwork period and, within 2 to 3 days, incubated in the laboratory at $20^{\circ} \mathrm{C}$ in the dark. Sampled trees were classified as small ( $<5 \mathrm{~cm}$ in diameter), medium (5 to $15 \mathrm{~cm}$ ), or large $(>15 \mathrm{~cm})$. Additionally, for 10 trees in each plot whose root systems were in contact with the water, the percentage of damaged trees was estimated by noting the presence or absence of Phytophthora spp. infection symptoms such as defoliation and dieback. During the fieldwork period, six plots with alder trees displaying active lesions were observed in areas that did not belong to the established sampling plots. In those cases, Phytophthora spp. isolation was attempted and the plot was added as an extra sampling plot in the stream. In order to keep the systematic impact assessment, the information from these extra plots was used only in the subspecies distribution analyses and not in the damage evaluation.

Isolation and identification procedures. Within 2 to 4 days following plating, the phloem tissue samples were examined for Phytophthora-like hyphae that were subsequently transferred onto PARPBH and incubated at $25^{\circ} \mathrm{C}$ for 4 days. Hyphal tips from putative pure cultures were transferred to V8 media and stored at $25^{\circ} \mathrm{C}$. Within 7 to 10 days, the growth pattern and possible oogonia formed were examined for a tentative $P$. alni subspecies identification (Brasier et al. 2004). All Phytophthora isolates, including those not resembling $P$. alni, were typed by molecular identification. Together with the isolates obtained from this study, we also conducted molecular identification of 39 isolates collected in earlier surveys in Sweden (Table 1).

For molecular identification, isolates were grown on V8 agar for 1 week and DNA was extracted from mycelia harvested from the active growing front using NucleoSpin Plant II (Macherey-Nagel). Putative $P$. alni isolates were confirmed to be $P$. alni by using the sequence-characterized amplified region-based polymerase chain reaction (PCR) primers PA-F and PA-R from Ioos et al. (2005). For subspecies identification, we performed two PCR rounds, the first with TRP-PAU-F/-R primers (positive signal for P. alni subspp. alni and uniformis isolates), and the second with RAS-PAM1-F/-R primers (positive signal for $P$. alni subspp. alni and multiformis isolates) (Ioos et al. 2006). Cycling conditions were as in the respective papers (Ioos et al. 2005, 2006). Unknown Phytophthora isolates were identified to species level based on the internal transcribed spacer (ITS) region. DNA was amplified using the ITS6f and ITS4 primers (Cooke and Duncan 1997; White et al. 1990) according to PCR conditions described by Samils et al. (2011) and sequenced by Macrogen. Blast searches in GenBank (http://www.ncbi.nlm.nih. gov/genbank/) showed that the isolates corresponded to $P$. plurivora. The ITS sequences were subsequently compared with putative related isolates found in Jung and Burgess (2009) using ITS sequences obtained from GenBank. Sequence data for the ITS region was aligned by Muscle and a neighbor-Joining tree was constructed in Mega software (version 6) using default settings.

TABLE 1. Distribution of Phytophthora alni isolates obtained in Sweden since $1996^{\mathrm{a}}$

\begin{tabular}{|c|c|c|c|c|c|c|c|c|c|c|c|c|c|}
\hline \multirow[b]{2}{*}{ Year } & \multirow[b]{2}{*}{ River code } & \multirow[b]{2}{*}{ River } & \multicolumn{5}{|c|}{ Number of Phytophthora isolates } & \multicolumn{6}{|c|}{ Number of plots with Phytophthora spp. } \\
\hline & & & Paa & $\mathrm{Pau}$ & Pam & Plu & Total & Paa & $\mathrm{Pau}$ & Pam & Paa and Pau & Plu & Total \\
\hline 1996 & 1 & Säveån & $\ldots$ & 4 & $\ldots$ & $\ldots$ & 4 & $\ldots$ & $\ldots$ & $\ldots$ & $\ldots$ & $\ldots$ & $\ldots$ \\
\hline 1998 & 2 & Mölndalsån & 1 & $\ldots$ & $\ldots$ & $\ldots$ & 1 & $\ldots$ & $\ldots$ & $\ldots$ & $\ldots$ & $\ldots$ & $\ldots$ \\
\hline \multirow[t]{4}{*}{2006} & 1 & Säveån & 1 & $\ldots$ & $\ldots$ & $\ldots$ & 1 & $\ldots$ & $\ldots$ & $\ldots$ & $\ldots$ & $\ldots$ & $\ldots$ \\
\hline & & Klarälven & $\ldots$ & 2 & $\ldots$ & $\ldots$ & 2 & $\ldots$ & $\ldots$ & $\ldots$ & $\ldots$ & $\ldots$ & $\ldots$ \\
\hline & 2 & Mölndalsån & 9 & $\ldots$ & 1 & $\ldots$ & 10 & $\ldots$ & $\ldots$ & $\ldots$ & $\ldots$ & $\ldots$ & $\ldots$ \\
\hline & 7 & Roneå & 4 & $\ldots$ & 1 & $\ldots$ & 5 & $\ldots$ & $\ldots$ & $\ldots$ & $\ldots$ & $\ldots$ & $\ldots$ \\
\hline \multirow[t]{2}{*}{2010} & 1 & Säveån & 12 & $\ldots$ & $\ldots$ & $\ldots$ & 12 & $\ldots$ & $\ldots$ & $\ldots$ & $\ldots$ & $\ldots$ & $\ldots$ \\
\hline & 2 & Mölndalsån & 4 & $\ldots$ & $\ldots$ & $\ldots$ & 4 & $\ldots$ & $\ldots$ & $\ldots$ & $\ldots$ & $\ldots$ & $\ldots$ \\
\hline \multirow[t]{16}{*}{2013} & 1 & Säveån & $\ldots$ & $\ldots$ & $\ldots$ & $\ldots$ & $\ldots$ & $\ldots$ & $\ldots$ & $\ldots$ & $\ldots$ & $\ldots$ & $\ldots$ \\
\hline & 2 & Mölndalsån & 7 & $\ldots$ & $\ldots$ & $\ldots$ & 7 & 3 & $\ldots$ & $\ldots$ & $\ldots$ & $\ldots$ & 3 \\
\hline & 3 & Örekilsälven & $\ldots$ & 2 & $\ldots$ & $\ldots$ & 2 & $\ldots$ & 1 & $\ldots$ & $\ldots$ & $\ldots$ & 1 \\
\hline & 4 & Viskan & 2 & 1 & $\ldots$ & $\ldots$ & 3 & 2 & 1 & $\ldots$ & $\ldots$ & $\ldots$ & 3 \\
\hline & 5 & Ätran & $\ldots$ & $\ldots$ & $\ldots$ & $\ldots$ & $\ldots$ & $\ldots$ & $\ldots$ & $\ldots$ & $\ldots$ & $\ldots$ & $\ldots$ \\
\hline & 6 & Lagan & $\ldots$ & 7 & $\ldots$ & $\ldots$ & 7 & - & 3 & $\ldots$ & $\ldots$ & $\ldots$ & 3 \\
\hline & 7 & Rönnea & 8 & 2 & $\ldots$ & 2 & 12 & 1 & 1 & $\ldots$ & 1 & 2 & 5 \\
\hline & 8 & Kävlingeå & 8 & 3 & $\ldots$ & $\ldots$ & 11 & 2 & 1 & $\ldots$ & $\ldots$ & $\ldots$ & 3 \\
\hline & 9 & Helgeå & 6 & 2 & $\ldots$ & $\ldots$ & 8 & 2 & 1 & $\ldots$ & $\ldots$ & $\ldots$ & 3 \\
\hline & 10 & Ronnebyån & 6 & 2 & $\ldots$ & $\ldots$ & 8 & 1 & 1 & $\ldots$ & 1 & $\ldots$ & 3 \\
\hline & 11 & Lyckebyån & 2 & 11 & $\ldots$ & $\ldots$ & 13 & 1 & 3 & $\ldots$ & $\ldots$ & $\ldots$ & 4 \\
\hline & 12 & Alsteran & $\ldots$ & 8 & $\ldots$ & $\ldots$ & 8 & $\ldots$ & 2 & $\ldots$ & $\ldots$ & $\ldots$ & 2 \\
\hline & 13 & Storån & $\ldots$ & 8 & $\ldots$ & 2 & 10 & $\ldots$ & 4 & $\ldots$ & $\ldots$ & 2 & 6 \\
\hline & 14 & Nykopingsån & $\ldots$ & 11 & $\ldots$ & 2 & 13 & $\ldots$ & 7 & $\ldots$ & $\ldots$ & 1 & 8 \\
\hline & 15 & Gävleån & $\ldots$ & 4 & $\ldots$ & $\ldots$ & 4 & $\ldots$ & 3 & $\ldots$ & $\ldots$ & $\ldots$ & 3 \\
\hline & 16 & Fyrisån & $\ldots$ & 7 & $\ldots$ & $\ldots$ & 7 & $\ldots$ & 2 & $\ldots$ & $\ldots$ & $\ldots$ & 2 \\
\hline
\end{tabular}

${ }^{a}$ In the survey of 2013, all rivers but Örekilsälven and Viskan had a total of 11 sampling plots. Total number of sampling plots in 2013 = 176. Paa $=$ Phytophthora alni subsp. alni, $\mathrm{Pau}=$ P. alni subsp. uniformis, $\mathrm{Pam}=$ P. alni subsp. multiformis, and $\mathrm{Plu}=P$. plurivora . 
Climatic data. Air temperature data were obtained from the Swedish Meteorological and Hydrological Institute website (luftweb.smhi.se). The database contains gridded daily temperature and precipitation data interpolated from weather station data with a resolution of 4 by $4 \mathrm{~km}$. The monthly average temperature and the average of the maximum period of consecutive days with temperatures below $-5^{\circ} \mathrm{C}$ for the last 20 years was calculated for each sampling plot.

Statistical analysis. We compared the average monthly temperature and the maximum number of consecutive days with temperatures below $-5^{\circ} \mathrm{C}$ between sampling plots with presence of $P$. alni subspp. alni and uniformis and without any Phytophthora spp. by a general linear model. Means were compared by Tukey's honestly significant difference at $P<0.05$. The same test was performed to compare the percentage of healthy trees between plots with the presence of $P$. alni subsp. uniformis and P. alni subsp. alni, those with $P$. plurivora, and those without apparent Phytophthora spp. damage. In order to test whether $P$. alni subsp. uniformis appeared more frequently in colder areas of the temperature distribution range of the host, we compared the median temperature of the coldest month of sampling plots with P. alni subsp. uniformis and all sampling plots together with the Mann-Whitney U nonparametric test. The association between the presence of $P$. alni subspp. uniformis and alni and February temperature was evaluated by logistic regression using logit as a link function and assuming a binomial distribution. All statistical tests were performed in Minitab (version 16.1.0; Minitab Inc.), except for the logistic regression that was performed in JMP Pro (version 11.0.0; SAS Institute Inc.).

\section{RESULTS}

Temperature-based $\boldsymbol{P}$. alni distribution. We observed symptoms of Phytophthora spp. in all but two of the sampled rivers, with an overall incidence of $28 \%$ across sampling plots. In total, we obtained 113 isolates from 157 alder trees with cankers. Two subspecies (P. alni subspp. uniformis and alni) were found (68 isolates in 31 plots, and 39 isolates in 13 plots, respectively). In addition, six $P$. plurivora isolates were also recovered from five plots (in three rivers). Although $P$. alni subsp. uniformis was present across the distribution range of the host, $P$. alni subsp. alni was restricted to southern coastal areas, associated with milder winter conditions (Fig. 1). The monthly average temperature of locations where P. alni subsp. alni was observed was systematically over or very close to $0^{\circ} \mathrm{C}$ (Fig. 2). P. alni subsp. alni was isolated in plots with an average temperature of the coldest month (February) of $-0.05^{\circ} \mathrm{C}$ (standard error $[\mathrm{SE}]=0.31$ ) and an average of maximum heavy frost duration of 4.45 days in length $(\mathrm{SE}=0.52)$. $P$. alni subsp. uniformis was recovered in significantly colder sampling plots than $P$. alni subsp. alni $\left(-1.75^{\circ} \mathrm{C} ; \mathrm{SE}=0.20\right)$, with average frost periods of 7.26 days $(\mathrm{SE}=0.34)$ (Fig. 2 and $3 \mathrm{~A})$. February average temperature was highly correlated $\left(R^{2}=0.97\right)$ with the maximum number of consecutive days with temperatures below $-5^{\circ} \mathrm{C}$ (Fig. 3B). Although observations of $P$. alni subsp. uniformis were recorded throughout the entire range of the host, they tended to be shifted toward colder locations (Fig. 2) (median February temperature in P. alni subsp. uniformis plots $=-2.0^{\circ} \mathrm{C}$ versus median all plots $=$ $-1.3^{\circ} \mathrm{C} ; P=0.036$ ) In contrast, $P$. alni subsp. alni observations were recorded in warmer locations (median February temperature in P. alni subsp. alni plots $=0.07^{\circ} \mathrm{C}$ versus median all plots $=-1.3^{\circ} \mathrm{C}$; $P<0.0001)$. The probability of finding $P$. alni subsp. uniformis in a plot decreased as the average February temperature increased $(P=0.027)$. In contrast, the probability of finding $P$. alni subsp. alni increased as the average February temperature increased $(P<0.0001)$.

Impact assessment. The impact assessment showed that $31 \%$ of the alder stands had $\geq 50 \%$ of the trees with symptoms of decline. In sampling plots with P. alni presence, the percentage of trees with a healthy crown was significantly lower than in plots without symptoms of the pathogen (54 versus $77 \%, P=0.02$ ) (Fig. 4). No differences were found between $P$. alni subspecies. The majority of infected trees were $A$. glutinosa (93\%), which is also the most common alder species in these river systems (as opposed to A. incana). The infected trees were more commonly found in sampling plots including river-connected swamps or ponds than plots restricted to river banks (57 isolates in 16 plots versus 56 isolates in 33 plots). The majority of Phytophthora colonies (86\%) were isolated from trees of less than $15 \mathrm{~cm}$ in diameter.

Morphological and molecular identification. Microscopic morphological identification matched molecular identification based upon specific primers and ITS sequence analysis. $P$. alni subsp. alni isolates displayed uniform growth in V8 agar; sparse aerial mycelium; and abundant, ornamented, brown, and sometimes comma-shaped oogonia with amphigynous antheridia. In contrast, P. alni subsp. uniformis showed irregular and dense aerial mycelium; less abundant and mostly smooth-walled oogonia, rarely displaying protuberances; with amphigynous antheridia. The growth pattern of $P$. plurivora was radiate and slightly chrysanthemum shaped, with limited aerial mycelium. Oogonia were extremely abundant, with paragynous antheridia, and developed rapidly in V8 agar.

\section{DISCUSSION}

Role of temperature in $P$. alni subspecies distribution. The geographical distribution of $P$. alni subspecies correlated with the monthly winter temperature and with the duration of heavy frost (consecutive days with temperature below $-5^{\circ} \mathrm{C}$ ). P. alni subsp. alni was isolated in the warmest locations of the studied area whereas P. alni subsp. uniformis was recovered within the whole temperature range of the host (Fig. 1). It could be hypothesized that the absence of $P$. alni subsp. alni in areas with average winter temperatures below $-1^{\circ} \mathrm{C}$ was because the duration of heavy frost periods impaired P. alni subsp. alni survival in those regions (Fig. 3). Previous studies have shown that, even though $P$. alni subsp. aln $i$ was able to tolerate temperatures as low as $-2.5^{\circ} \mathrm{C}$, the survival rate decreases rapidly when temperature was between -5 and $-10^{\circ} \mathrm{C}$ for several consecutive days (Černý and Strnadová 2012; Černý et al. 2012). In Sweden, locations with average February temperatures of $-2.5^{\circ} \mathrm{C}$, where $P$. alni subsp. alni is currently absent, can occasionally undergo frost periods twice as long as in other regions in Europe, where $P$. alni subsp. alni has been reported under similar temperature conditions ( 4 days in Czech Republic versus 8 days in Sweden) (Černý et al. 2012) (Fig. 3B). We suggest that the observed distribution of $P$. alni reflects the differences in cold and frost tolerance between P. alni subspp. alni and uniformis. Possibly, these differences are explained by their capacity to produce viable overwintering structures (i.e., P. alni subsp. alni generally produces fewer viable oospores than $P$. alni subsp. uniformis) (Delcán and Brasier 2001).

An alternative but less likely explanation for the limited distribution of $P$. alni subsp. alni in southern Sweden could be a more recent introduction of $P$. alni subsp. alni than $P$. alni subsp. uniformis. The observed distribution of $P$. alni subsp. alni would then be part of an ongoing northward expansion over areas previously occupied by $P$. alni subsp. uniformis (Štěpánková et al. 2013). However, there seems to be little evidence supporting that hypothesis. On the one hand, it is known from historical data that both $P$. alni subspp. alni and uniformis were present in Sweden since the 1990 s, discarding a recent introduction of P. alni subsp. alni. On the other hand, because both subspecies are invasive in Sweden and they presumably spread by the same route of invasion, there seems to be little support for a faster dispersion of $P$. alni subsp. uniformis than of P. alni subsp. alni. Within similar time frames (2000 to 2013) but under less harsh winter conditions, other studies have shown that $P$. alni subsp. alni rapidly spread and dominated entire areas where $P$. alni subsp. uniformis was presumably established before (Štěpánková et al. 2013). Although perhaps $P$. alni subsp. alni 
is still not covering its entire potential range, we argue that this replacement has not occurred in northern areas of Sweden because low winter temperatures and long periods of heavy frost occurring in these locations play a role in hampering such expansion.

The current distribution of the subspecies of $P$. alni could also be the consequence of different geographical introductions among subspecies. Initial $P$. alni introductions in Sweden have probably occurred via infected nursery stock. Both $P$. alni subspp. alni and uniformis were first reported in Sweden in southwest nurseries and alder-planted areas during the 1990s (C. H. B. Olsson, unpublished results). During the present survey, both $P$. alni subspecies have been recovered from several riverbank alder plantations (Supplementary Fig. S1D). After P. alni establishment in rivers via alder plantations, further spread might have occurred via wild animal migrations or livestock and human movements (Adams et al. 2010;

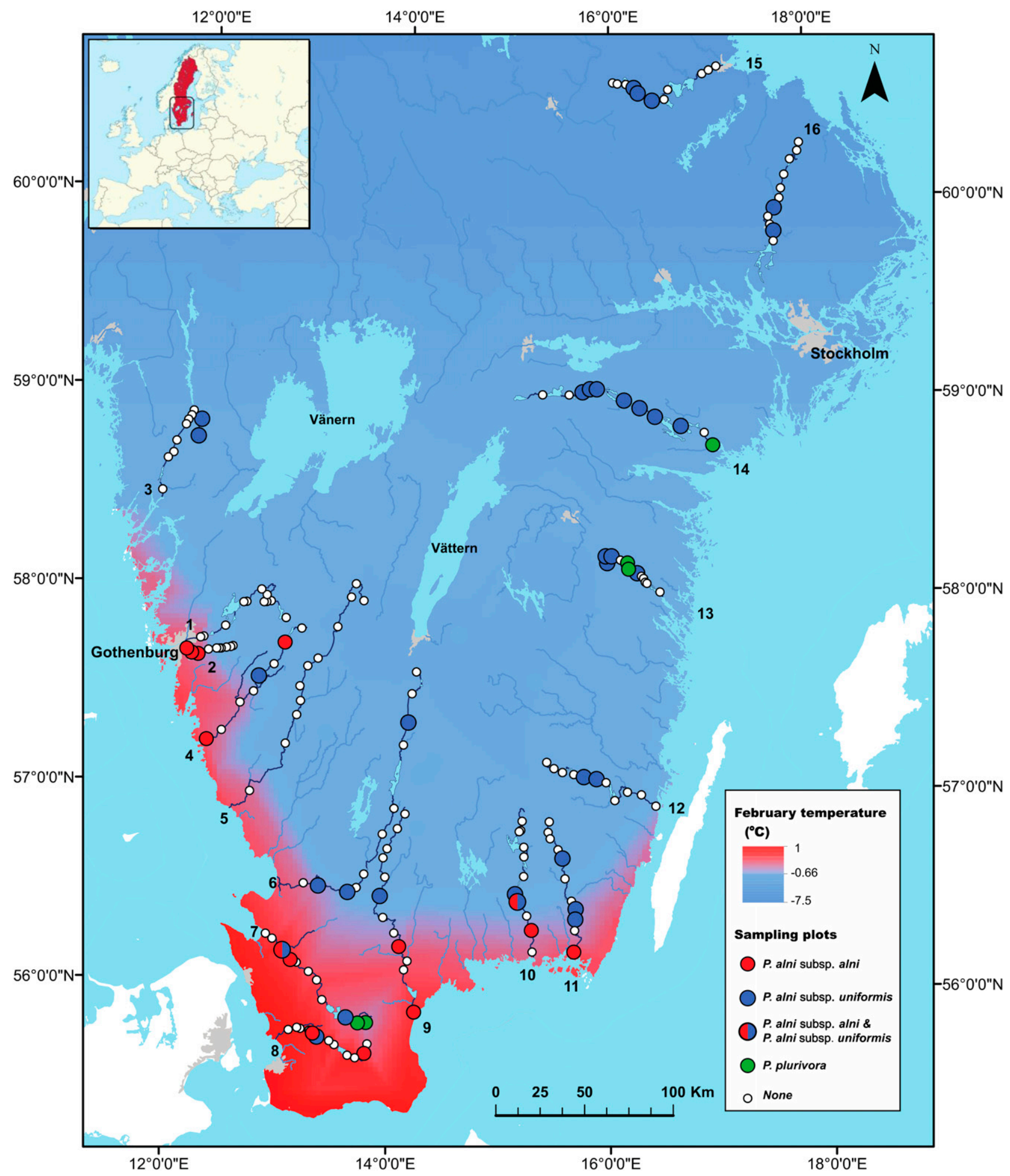

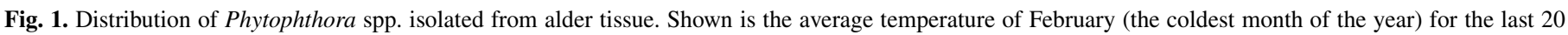

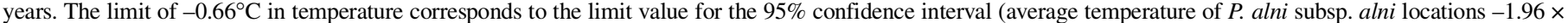
standard error). "None" indicates absence of the species. The number for each river corresponds to the river code in Table 1. 
Webber and Rose 2008). Because P. alni subsp. alni is more often present in nursery stock than $P$. alni subsp. uniformis (Jung and Blaschke 2004; Schumacher et al. 2006), the abundance of P. alni subsp. alni in coastal areas might be related to higher planting activities as a consequence of a higher human density in these regions. However, P. alni subsp. alni only dominates coastal areas when these are located in the warmest areas of Sweden, whereas it appeared to be absent in more northern and colder coastal areas. To our knowledge, there seems to be no reason why P. alni subsp. alni would have been introduced more often in southern than in northern Sweden.

We found indications that $P$. alni subsp. alni might be replacing P. alni subsp. uniformis in climatically suitable areas. $P$. alni subsp. uniformis was observed across the entire range of temperatures of the host, although findings tended to be more common in the colder locations of the studied area. When looking at intrasite distribution, P. alni subsp. uniformis was present in only 2 of 14 locations where P. alni subsp. alni was observed. Previous observations in Sweden also support a local replacement. During the first $P$. alni surveys performed in the 1990s, both P. alni subspp. alni and uniformis were isolated. In Säveån, $P$. alni subsp. uniformis was first isolated in 1996 but, in 2006 and 2010, only P. alni subsp. alni was recovered from the same river system (Table 1). In contrast, $P$. alni subsp. alni has been systematically recovered in Mölndalsån (in 1998, 2006,
2010, and 2013), indicating that, where established, $P$. alni subsp. alni became prevalent in the long run. Most likely, P. alni subsp. alni is able to suppress $P$. alni subsp. uniformis in some areas due to its higher virulence (Brasier and Kirk 2001; Štěpánková et al. 2013). Replacement of well-established invasive or native pathogens with more virulent strains has been observed in other pathosystems such as Ophiostoma novo-ulmi replacing O. ulmi in Europe (Brasier and Buck 2001) or Heterobasidion irregulare replacing H. annosum s.s. in Italy (Garbelotto et al. 2010). To confirm the replacement, more isolations per site should be carried out, possibly complemented with isolation from the rhizosphere in order to confirm the absence of $P$. alni subsp. uniformis in areas where $P$. alni subsp. alni is present.

Impact assessment. In southern Sweden, $P$. alni was widespread in river systems, with $28 \%$ of sampling plots associated with severe decline crown symptoms. Similar observations have been reported in other Southern and Central European countries (Gibbs et al. 2003; Jung and Blaschke 2004; Streito et al. 2002). The results of the crown health assessment performed showed that the percentage of healthy crowns in the plots with $P$. alni was significantly lower than in the plots without this pathogen (Fig. 4).

Nevertheless, there was a large variation of alder health status in places where Phytophthora symptoms were observed. A reason for that could be that we observed Phytophthora spp. in sites where they had just established, and damages had not yet been manifested in the
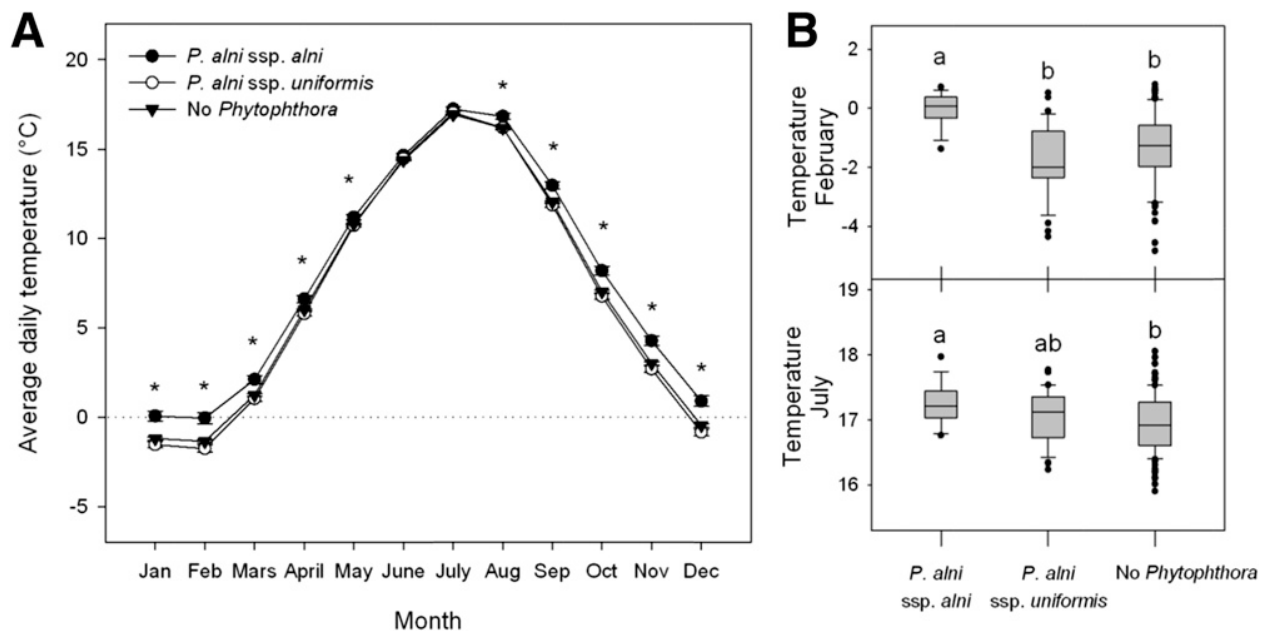

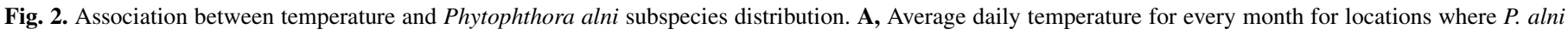

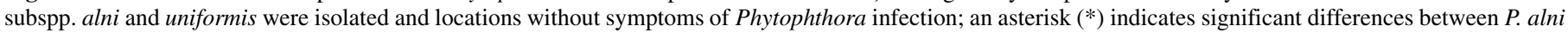

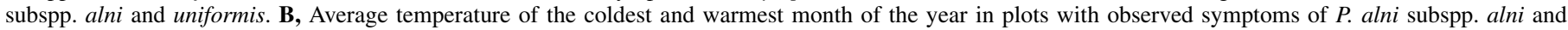
uniformis. The line inside the box indicates the median temperature.
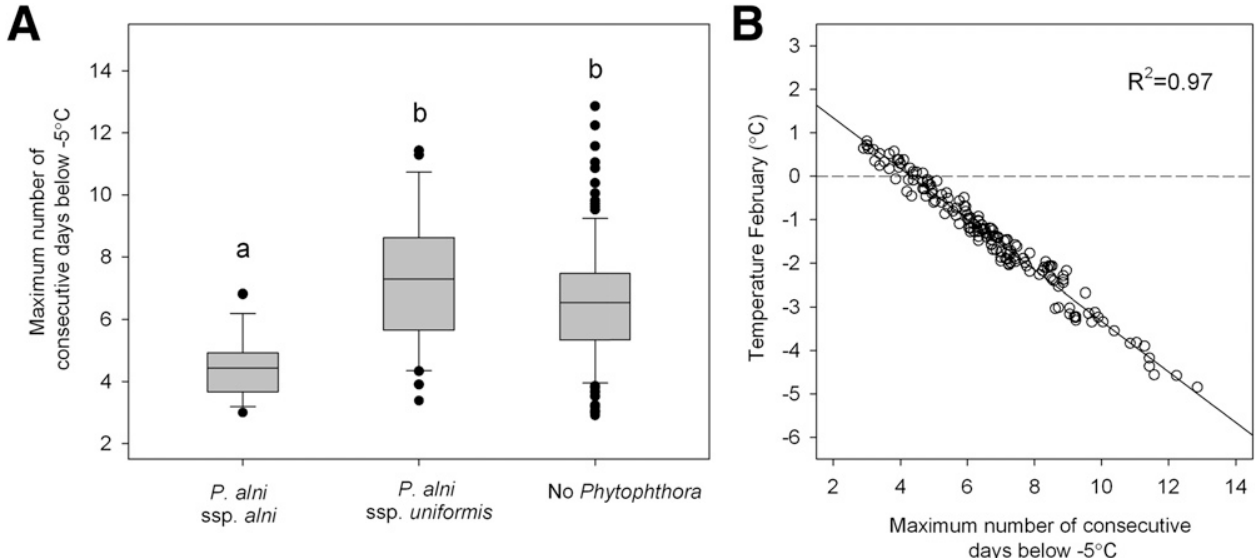

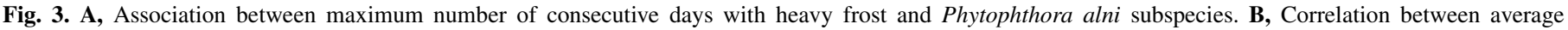
February temperature and duration of heavy frost period for the last 20 years in southern Sweden. 
dominant trees assessed. It has been previously observed that trees marked with active lesions still displayed a healthy-looking crown (Jung and Blaschke 2004; Thoirain et al. 2007). Occasionally, alder trees can also recover from decline (Aguayo et al. 2014). It can also be considered that many alder trees eventually die from the attack of secondary pathogens such as Inonotus or Armillaria spp. (Jung and Blaschke 2004). Consequently, high variation in health estimations can be related to the presence or absence of these secondary pathogens. Damage differences between $P$. alni subspecies were not observed, in contrast with previous observations of pathogenicity tests in seedlings (Brasier and Kirk 2001). A possible explanation could be that $P$. alni subsp. alni aggressiveness was decreased in Sweden by cold climate or short vegetative period, resulting in a similar aggressiveness of subspecies.

At the river scale, the rate of infected trees per plot was higher in flooded areas than in riverbank sites (3.6 and 1.7 isolates/plot, respectively). Some of the flooded areas were also highly disturbed sites in which cattle had been grazing. Swamps and ponds could be considered hot spots that might act as inoculum sources facilitating downstream spread of Phytophthora spp. (Jung and Blaschke 2004; Schumacher et al. 2006; Streito et al. 2002; Thoirain et al. 2007). The role of cattle movement as a vector for spreading Phytophthora spp. could be considered in future studies.

In five locations, $P$. plurivora was also isolated from alder bark tissue constituting additional reports of $P$. plurivora in alder trees in Sweden (Fig. 1). Earlier reports of $P$. plurivora on alder in Sweden correspond to the isolations made in Asslebyn (Bengtsfors locality) in Sept 2012, although P. plurivora isolates had been previously obtained from surveys near Nyköping in 1999 (C. H. B. Olsson, unpublished results). P. plurivora is an invasive species infecting a wide range of host species, previously observed in other European countries also infecting alder (Haque et al. 2014; Jung and Blaschke 2004; Jung and Burgess 2009). Due to its potential to affect multiple woody species, the presence of $P$. plurivora in water streams could facilitate the spread to adjacent ecosystems, such as oak, beech, and Norway spruce forests (Jung and Burgess 2009; Rytkönen et al. 2013).

The results of the present work showed that winter conditions could affect the distribution of the different subspecies of $P$. alni in southern Sweden, thus limiting further spread of P. alni subsp. alni. The high incidence and widespread damage caused by $P$. alni poses a threat to Swedish riverbank ecosystems and requires further impact monitoring and research on dispersal pathways. Climatic

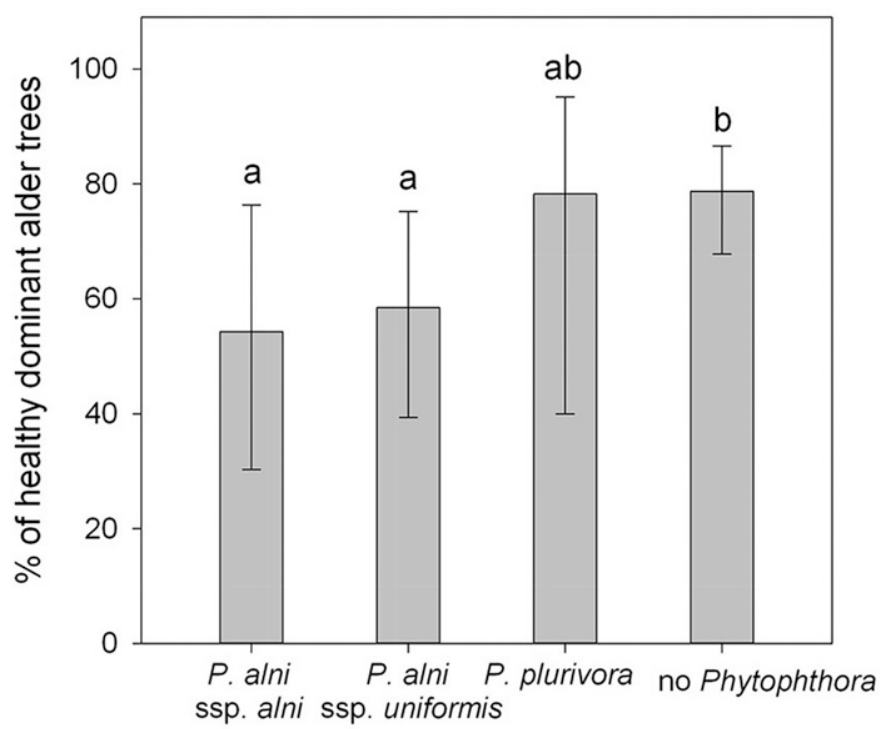

Fig. 4. Percentage of healthy trees in the sampling plots with presence and absence of Phytophthora spp. suitability has been suggested as a major determinant for invasiveness in forest pathogens (Aguayo et al. 2014). The results of the present work support that idea, and suggest that low temperatures in Northern Europe could currently be preventing the establishment of invasive forest pathogens. Consequently, a future warmer climate could enable higher invasion rates.

\section{ACKNOWLEDGMENTS}

This research was partly funded by the Swedish Research Council FORMAS with the grant 215/2015/1255 and the COST action PERMIT, the SNS EFINORD "Preventive and restorative measures to reduce damage on forests-Phytophthora diseases in focus", and the Biodiversa RESIPATH project and the research program Future Forests, financed by Mistra foundation, the forest faculty at SLU, and Swedish forest industry. We thank P. Sedlák, M. Jonsson, and E. Stenström for field assistance; and two anonymous reviewers for valuable comments on an earlier version of this article.

\section{LITERATURE CITED}

Adams, G. C., Catal, M., and Trummer, L. 2010. Distribution and severity of alder Phytophthora in Alaska. Pages 29-49 in: Sudden Oak Death Fourth Science Symp. S. J. Frankel, J. T. Kliejunas, and K. M. Palmieri, eds. Gen. Tech. Rep. PSW-GTR-229. Pacific Southwest Research Station, Forest Service, United States Department of Agriculture, Albany, CA.

Aguayo, J., Elegbede, F., Husson, C., Saintonge, F.-X., and Marçais, B. 2014. Modeling climate impact on an emerging disease, the Phytophthora alni induced alder decline. Glob. Change Biol. 20:3209-3221.

Bergot, M., Cloppet, E., Pérarnaud, V., Déqué, M., Marçais, B., and Desprez-Loustau, M.-L. 2004. Simulation of potential range expansion of oak disease caused by Phytophthora cinnamomi under climate change. Glob. Change Biol. 10:1539-1552.

Brasier, C. 1996. Phytophthora cinnamomi and oak decline in southern Europe. Environmental constraints including climate change. Ann. Sci. For. 53:347-358.

Brasier, C. M., and Buck, K. W. 2001. Rapid evolutionary changes in a globally invading fungal pathogen (Dutch elm disease). Biol. Invas. 3:223-233.

Brasier, C. M., and Kirk, S. A. 2001. Comparative aggressiveness of standard and variant hybrid alder phytophthoras, Phytophthora cambivora and other Phytophthora species on bark of Alnus, Quercus and other woody hosts. Plant Pathol. 50:218-229.

Brasier, C. M., Kirk, S. A., Delcan, J., Cooke, D. E. L., Jung, T., and Man In't Veld, W. A. 2004. Phytophthora alni sp. nov. and its variants: Designation of emerging heteroploid hybrid pathogens spreading on Alnus trees. Mycol. Res. 108:1172-1184.

Brasier, C. M., Rose, J., and Gibbs, J. N. 1995. An unusual Phytophthora associated with widespread alder mortality in Britain. Plant Pathol. 44:999-1007.

Černý, K., Filipová, N., and Strnadová, V. 2012. Influence of low temperature and frost duration on Phytophthora alni subsp. alni viability. For. Syst. 21: 337-342.

Černý, K., and Strnadová, V. 2012. Winter survival of Phytophthora alni subsp. alni in aerial tissues of black alder. J. For. Sci. 58:328-336.

Cooke, D. E. L., and Duncan, J. M. 1997. Phylogenetic analysis of Phytophthora species based on ITS1 and ITS2 sequences of the ribosomal RNA gene repeat. Mycol. Res. 101:667-677.

Delcán, J., and Brasier, C. M. 2001. Oospore viability and variation in zoospore and hyphal tip derivatives of the hybrid alder Phytophthoras. For. Pathol. 31:65-83.

Dukes, J. S., Pontius, J., Orwig, D., Garnas, J. R., Rodgers, V. L., Brazee, N., Cooke, B., Theoharides, K. A., Stange, E. E., Harrington, R., Ehrenfeld, J., Gurevitch, J., Lerdau, M., Stinson, K., Wick, R., and Ayres, M. 2009. Responses of insect pests, pathogens, and invasive plant species to climate change in the forests of northeastern North America: What can we predict? Can. J. For. Res. 39:231-248.

Fabre, B., Piou, D., Desprez-Loustau, M.-L., and Marçais, B. 2011. Can the emergence of pine Diplodia shoot blight in France be explained by changes in pathogen pressure linked to climate change? Glob. Change Biol. 17: 3218-3227.

Garbelotto, M., Linzer, R., Nicolotti, G., and Gonthier, P. 2010. Comparing the influences of ecological and evolutionary factors on the successful invasion of a fungal forest pathogen. Biol. Invas. 12:943-957.

Gibbs, J. N. 1995. Phytophthora root disease of alder in Britain. EPPO Bull. 25:661-664.

Gibbs, J. N., Lipscombe, M. A., and Peace, A. J. 1999. The impact of Phytophthora disease on riparian populations of common alder (Alnus glutinosa) in southern Britain. Eur. J. For. Pathol. 29:39-50.

Gibbs, J. N., van Dijk, C., and Webber, J. F. 2003. Phytophthora Disease of Alder in Europe. Forestry Commission Bull. No. 126. 
Haque, M. M., Martínez-Álvarez, P., Lomba, J. M., Martín-García, J., and Diez, J. J. 2014. First Report of Phytophthora plurivora causing collar rot on Common Alder in Spain. Plant Dis. 98:425.

Ioos, R., Andrieux, A., Marçais, B., and Frey, P. 2006. Genetic characterization of the natural hybrid species Phytophthora alni as inferred from nuclear and mitochondrial DNA analyses. Fungal Genet. Biol. 43:511-529.

Ioos, R., Husson, C., Andrieux, A., and Frey, P. 2005. SCAR-based PCR primers to detect the hybrid pathogen Phytophthora alni and its subspecies causing alder disease in Europe. Eur. J. Plant Pathol. 112:323-335.

Ireland, K. B., Hardy, G. E. S. J., and Kriticos, D. J. 2013. Combining inferential and deductive approaches to estimate the potential geographical range of the invasive plant pathogen, Phytophthora ramorum. PLoS One $8: \mathrm{e} 63508$.

Jeffers, S. N., and Martin, S. B. 1986. Comparison of two media selective for Phytophthora and Pythium species. Plant Dis. 70:1038-1043.

Jung, T., and Blaschke, M. 2004. Phytophthora root and collar rot of alders in Bavaria: Distribution, modes of spread and possible management strategies. Plant Pathol. 53:197-208.

Jung, T., and Burgess, T. I. 2009. Re-evaluation of Phytophthora citricola isolates from multiple woody hosts in Europe and North America reveals a new species, Phytophthora plurivora sp. nov. Persoonia 22:95-110.

Olsson, C. H. B. 1999. Diagnosis of root-infecting Phytophthora spp. Acta Univ. Agric. Sueciae Agrar. No. 161. Ph.D. thesis, Sveriges Lantbruksuniversitet (Swedish University of Agricultural Sciences) Uppsala, Sweden.

Pérez-Sierra, A., León, M., Álvarez, L. A., Alaniz, S., Berbegal, M., García-Jiménez, J. 2010. Outbreak of a new Phytophthora sp. associated with severe decline of Almond Trees in Eastern Spain. Plant Dis. 94: 534-541.

Rytkönen, A., Lilja, A., Werres, S., Sirkiä, S., and Hantula, J. 2013. Infectivity, survival and pathology of Finnish strains of Phytophthora plurivora and Ph. pini in Norway spruce. Scand. J. For. Res. 28:307-318.

Samils, B., Ihrmark, K., Kaitera, J., Stenlid, J., and Barklund, P. 2011. New genetic markers for identifying Cronartium flaccidum and Peridermium pini and examining genetic variation within and between lesions of Scots pine blister rust in Sweden. Fungal Biol. 115:1303-1311.

Santini, A., Barzanti, G. P., and Capretti, P. 2003. Susceptibility of some mesophilic hardwoods to alder Phytophthora. J. Phytopathol. 151:406-410.
Santini, A., Ghelardini, L., De Pace, C., Desprez-Loustau, M. L., Capretti, P., Chandelier, A., Cech, T., Chira, D., Diamandis, S., Gaitniekis, T., Hantula, J., Holdenrieder, O., Jankovsky, L., Jung, T., Jurc, D., Kirisits, T., Kunca, A., Lygis, V., Malecka, M., Marcais, B., Schmitz, S., Schumacher, J., Solheim, H., Solla, A., Szabò, I., Tsopelas, P., Vannini, A., Vettraino, A. M., Webber, J., Woodward, S., and Stenlid, J. 2013. Biogeographical patterns and determinants of invasion by forest pathogens in Europe. New Phytol. 197:238-250.

Schumacher, J., Leonhard, S., Grundmann, B. M., and Roloff, A. 2006. New alder disease in Spreewald biosphere reserve-Causes and incidental factors of an epidemic. Nachrichtenbl. Dtsch. Pflanzenschutzdienstes 58:141-147.

Stenlid, J., Oliva, J., Boberg, J. B., and Hopkins, A. J. M. 2011. Emerging diseases in European forest ecosystems and responses in society. Forests 2: 486-504.

Štěpánková, P., Černý, K., Strnadová, V., Hanáček, P., and Tomšovský, M. 2013. Identification of Phytophthora alni subspecies in riparian stands in the Czech Republic. Plant Prot. Sci. 49:S3-S10.

Streito, J.-C., Legrand, P., Tabary, F., and Villartay, G. J. D. 2002. Phytophthora disease of alder (Alnus glutinosa) in France: Investigations between 1995 and 1999. For. Pathol. 32:179-191.

Sturrock, R. N., Frankel, S. J., Brown, A. V., Hennon, P. E., Kliejunas, J. T., Lewis, K. J. 2011. Climate change and forest diseases. Plant Pathol. 60: 133-149.

Thoirain, B., Husson, C., and Marçais, B. 2007. Risk factors for the Phytophthora-induced decline of alder in northeastern France. Phytopathology 97:99-105.

Webber, J. F., and Rose, J. 2008. Dissemination of aerial and root infecting Phytophthoras by human vectors. Pages 195-198 in: Proc. Sudden Oak Dearth Third Sci. Symp. S. J. Frankel, J. T. Kliejunas, and K. M. Palmieri, eds. Gen. Tech. Rep. PSW-GTR-214. Pacific Southwest Research Station, Forest Service, United States Department of Agriculture, Albany, CA.

White, T., Bruns, T., Lee, S., and Taylor, J. 1990. Amplification and direct sequencing of fungal ribosomal RNA genes for phylogenetics. Pages 315-322 in: PCR Protocols: A Guide to Methods and Applications. M. A. Innis, D. H. Gelfand, J. J. Sninsky, and T. J. White, eds. Academic Press, San Diego, CA.

Woods, A., Coates, K. D., and Hamann, A. 2005. Is an unprecedented Dothistroma needle blight epidemic related to climate change? Bioscience 55:761-769. 